\title{
ANALISIS PENYELENGGARAAN PEMILIHAN KEPALA DESA SERENTAK
}

\author{
Alfrid Sentosa \\ Fakultas IImu Sosial dan IImu Politik Universitas PGRI Palangka Raya \\ (email: afrael09@gmail.com)
}

Aston Pakpahan

Fakultas Ekonomi dan Bisnis Universitas Palangka Raya

(email: astonantonius62@feb.upr.ac.id)

Della Eka Pratama

Fakultas IImu Sosial dan IImu Politik Universitas PGRI Palangka Raya

\begin{abstract}
Abstrak
Penelitian ini bertujuan untuk mengetahui 1) untuk mengetahui dan menggambarkan penyelenggaraan pemilihan kepala desa serentak di Desa Bandar Agung Kecamatan Parenggean, 2) Untuk mengetahui dan menggambarkan faktorfaktor yang menghambat dan mendukung penyelenggaraan pemilihan kepala desa serentak di Desa Bandar Agung Kecamatan Parenggean.

Pendekatan yang dilakukan dalam penelitian ini adalah pendekatan kualitatif. Pendekatan kualitatif ini bertujuan untuk mengungkap informasi kualitatif sehingga lebih menekankan pada masalah proses dan makna dengan cara mendeskripsikan permasalahan secara factual, sistematik dan akurat. Melalui pendekatan kualitatif ini, data dan informasi diterjemahkan dan diinterpretasikan sedemikian rupa sehingga proses pemilihan kepala desa serentak di Kecamatan Parenggean dapat terlihat sebagaiaman mestinya.

Adapun yang menjadi informan dalam penelitian ini terdiri atas: Camat Parenggean, Kepala Badan Pemerintahan Desa, Panitia Pelaksana, Kepala Desa terpilih, Kepala Desa tidak terpilih, Tim Sukses Calon,Tokoh Masyarakat. Teknik pengumpulan data penelitian dilakukan dengan wawancara dan dokumentasi

Hasil Penelitian: 1) Pelaksanaan Pemilihan Kepala Desa Serentak di Desa Bandar Agung dimulai dari tahapan Persiapan, Pencalonan hingga pemungutan suara dapat penulis simpulkan bahwa telah berjalan sesuai dengan prosedur tetapi harus lebih teliti lagi dalam melakukan pemeriksaan terhadap persyaratan calon yang meliputi verifikasi dan klarifikasi kelengkapan dan keabsahan administrasi pencalonan. Pada tahapan pemungutan suara berjalan dengan aman dan lancar serta masyarakat yang menggunaka hak suaranya $\pm 98,6 \%$. Angka yang baik jika diukur dari tingkat partisipasi masyarakat dalam memilih pemimpin Desa. 2) Adapun Faktor yang mempengaruhi jalannya pelaksanaan Pemilihan Kepala Desa serentak adalah Pertama, ketidak jelasan tentang persyaratan ijazah bagi calon. Kedua, Kurang telitinya panitia pemelihan tingkat desa dalam memverifikasi berkas calon.
\end{abstract}

\section{Kata kunci : Pemilihan Kepala Desa}

\section{Jurnal Sociopolitico}


Pendahuluan

Demokrasi telah menjadi pilihan bangsa Indonesia sejak proklamasi kemerdekaan tanggal 17 Agustus 1945. Pancasila yang merupakan Ideologi bangsa Indonesia mengharuskan negara kita memilihnya. Dalam Sila Keempat Pancasila yang berbunyi "kerakyatan yang dipimpin oleh hikmat kebijaksanaan dalam permusyawaratan/perwakilan" menjadi dasar pengakuan kedaulatan rakyat yang merupakan prinsip dasar demokrasi.

Demokrasi Indonesia merupakan demokrasi konstitusional, hal ini ditandai dengan kekuasaan pemerintah dibatasi dalam suatu konstitusi.(Miriam Budiardjo. 2010) Pembatasan kekuasaan pemerintah ini tercantum dalam konstitusi Negara Indonesia di dalam Pasal 1 ayat (2) dan ayat (3) UUD 1945 amandemen ketiga, yaitu " Kedaulatan berada di tangan rakyat dan dilaksanakan menurut UndangUndang Dasar" dan "Negara Indonesia adalah negara hukum".

Pembatasan kekuasaan ini pada dasarnya bertujuan agar pemerintah tidak sewenang-wenang terhadap warga negaranya. Hal ini sejalan dengan pendapat ahli sejarah Inggris Lord Acton yang mengatakan bahwa "manusia yang mempunyai kekuasaan cenderung untuk menyalahgunakan kekuasaan itu, tetapi manusia yang mempunyai kekuasaan tak terbatas pasti akan menyalahgunakannya secara tak terbatas pula"..(Miriam Budiardjo. 2010).

Tuntutan dari reformasi yang berujung desentralisasi ini sebenarnya membawa judul besar perubahan yaitu demokratisasi, dimana demokratisasi yang dipahami dalam skala nasional digiring masuk ke pemerintahan daerah dengan harapan pembangunan demokratis merata diseluruh Indonesia, baik dalam kehidupan sosial maupun dalam kehidupan perpolitikan nasional. Perubahan dalam tata kelola politik pemerintahan diantaranya adalah sistem kepartaian, sistem pemilihan umum, dan hubungan antara pemerintah pusat dan pemerintah daerah. Ketiga komponen ini memiliki pengaruh serius terhadap kehidupan politik pada level desa. Konsekuensinya, frekuensi penduduk desa mngikuti pemilihan umum semakin tinggi.

Dalam kurun waktu lima tahun, paling tidak mereka akan mengikuti empat pemilu yakni: pemilu Presiden/wakil presiden, pemilu anggota DPR/DPD/DPRD, pemilu gubernur/wakil gubernur, pemilu bupati/wakil bupati dan/atau walikota/wakil walikota, serta oemilihan kepala desa (pilkades). Maka dari itu, tatkala reformasi merubah hubungan pemerintah pusat dengan pemerintah daerah melalui kebijakan desentarlisasi yang diaplikasikan sejak 1999, jarak proses pembuatan keputusan politiksemakin pendek dan pemerintah daerah semakin memiliki ruang manuver lebih besar untuk mempercepat pembangunan daerah. Hal ini berujung pada pengambilan keputusan politik yang lebih demokratis karena rakyat sudah merasa dekat dengan pemimpinnya.

Walaupun demokrasi menjadi pilihan para pendiri bangsa, perkembangan demokrasi di Indonesia telah mengalami pasang surut. Selama 71 tahun berdirinya Negara Kesatuan Republik Indonesia mengalami hambatan yang dapat mempengaruhi stabilitas politik yang mengancam keutuhan Negara Kesatuan Republik Indonesia. Nilai demokrasi pernah disingkirkan sebelum kembali menjadi satu arus utama di era reformasi. Setelah pemerintahan Orde Baru ditumbangkan pada bulan Mei 1998,

\section{Jurnal Sociopolitico}


bangsa Indonesia telah menunjukkan komitmen untuk kembali ke demokrasi. Komitmen bangsa Indonesia ditunjukkan melalui banyaknya perubahan yang mendasar dalam sistem pemerintahan Indonesia.

Demokrasi menuntut adanya partisipasi aktif dari rakyat dalam proses pengambilan kebijakan politik. Rakyat dilibatkan dalam pembuatan keputusan yang dilakukan oleh pemerintah, sehingga kepentingan rakyat dapat tercermin dalam kebijakan-kebijakan pemerintahannya. Setiap kebijakan pemerintah merupakan cerminan atau repsentatif kepentingan rakyat. (Muslim Mufti, Didah Durrotun, 2013).

\section{Mennurut Robert Dahl} sebagaimana yang dikutip Mas'oed bahwa:

"sebuah Negara menjadi demokratis ketika pemilihan umum telah dilaksanakan, hak pilih universal diberikan, didukung oleh kebebasan berserikat, berkumpul dan menyuarakan aspirasi di muka umum. Pendek kata bagi Dahl, demokrasi adalah tatanan politik yang sangat liberal dan aspiratif yang memungkinkan semua orang masuk dalam kempetisi dan kontestasi. Karena itu wajar apabila demokrasi kita tidak begitu peka dengan masalah pemenuhan kebutuhan dasar warga Negara sebagai syarat bagi kesejahteraan unversal." (Mas'oed Mohtar 2003).

Salah satu perubahan mendasar dalam sistem pemerintahan Indonesia dari era orde baru ke era reformasi adalah lahirnya UU Nomor 6 Tahun 20014 tentang desa. Salah satu yang diatur dalam UU Nomor 6 adalah tentang pemilihan kepala desa.

Desa adalah desa dan desa adat atau yang disebut dengan nama lain, selanjutnya disebut Desa, adalah kesatuan masyarakat hukum yang memiliki batas wilayah yang berwenang untuk mengatur dan mengurus urusan pemerintahan, kepentingan masyarakat setempat berdasarkan prakarsa masyarakat, hak asal usul, dan/atau hak tradisional yang di akui dan di hormati dalam sistem pemerintahan Negara Kesatuan Republik Indonesia. Pernyataan tersebut tercantum dalam Undang-Undang No.6 tahun 2014 tentang Desa. Maka Desa berhak menyelenggarakaan urusan pemerintahan dan membentuk pemerintahan yang sesuai dengan pedoman pelaksanaan ketatanegaraan Republik Indonesia yang berdasarkan Pancasila dan UndangUndang Dasar 1945.

Pemilihan kepala desa (Pilkades) merupakan pesta demokrasi ditingkat Desa, dimana masyarakat desa dapat berpartisipasi dengan memberikan suara untuk memilih calon kepala desa yang bertanggung jawab dan dapat mengembangkan desa tersebut. Oleh karena itu, pemilhan kepala desa sangat penting, karena sangat mendukung penyelenggaraan pemerintahan desa. Dalam penyelenggaraan Pilkades, pemerintah kabupaten sebagai penyelenggara harus mapan dalam memahami proses demokrasi pada tingkat desa, apalagi pemilihan Kepala Desa sesuai tuntutan undang-undang No.6 Tahun 2014 bahwa pemilihan harus dilaksanakan secara serentak di seluruh wilayah Kabupaten. Bukan hal yang mudah tentunya bagi Kabupaten karena tidak hanya sebagai penyelenggara tetapi juga sebagai pengawas jalannya pemilihan. Sebagaimana ditegaskan dalam undang-undang desa Tahun 2014 Pasal 31 ayat (1) dan (2).

\section{Jurnal Sociopolitico}


1) Pemilihan Kepala Desa dilaksanakan secara serentak di seluruh wilayah Kabupaten/Kota.

2) Pemerintahan

Daerah

Kabupaten/Kota

menetapkan

kebijakan pelaksanaan pemilihan Kepala Desa secara serentak sebagaimana dimaksud pada ayat

(1) dengan Peraturan Daerah Kabupaten/Kota

Untuk melaksanakan pemerintahan di desa diperlukan adanya pimpinan penyelenggaraan pemerintahan, yaitu Kepala Desa terpilih hasil dari pemilihan yang demokratis, jujur, dan adil oleh warga yang telah mempunyai hak pilih. Dalam pelaksanaan pemilihan kepala desa serentak, diatur dalam Peraturan Pemerintah Nomor 43 Tahun 2014 tentang pelaksanaan Undang-Undang Nomor 6 Tahun 2014 Tentang Desa dan Peraturan Menteri Dalam Negeri Nomor 112 Tahun 2014 Tentang Pemilihan Kepala Desa, serta Peraturan Bupati Bone Nomor 44 Tahun 2015 Tentang pelaksanaan Peraturan Daerah Nomor 1 tahun 2015 tentang pemilihan, pelantikan, dan pemberhentian kepala desa.

Penyelenggara pemilihan kepala desa serentak harus independen dalam segala tindakannya agar penyelenggaraan pemilihan kepala desa serentak berjalan bersih dan adil tanpa adanya intervensi dari pihak lain. Instansi maupun individu yang melakukan pengawasan pemilihan kepala desa serentak juga harus mampu melakukan pengawasan yang dapat dipercaya sehingga penyelenggaraan pemilihan kepala desa serentak berjalan sesuai dengan aturan. Pemerintah daerah harus mampu mendukung penyelenggara pemilihan kepala desa serentak dan bersifat netral sehingga pemilihan kepala desa serentak dapat berjalan efektif dan tidak adanya pemanfaatan birokrasi maupun fasilitas negara untuk mendukung calon tertentu yang dapat mengurangi hakikat dari demokrasi. Dan masyarakat juga harus mampu berpikir rasional dalam memilih, sehingga terpilih pemimpin yang berkualitas.

Dilihat dari jumlah Desa yang melaksanakan pemilihan cukup banyak, tentunya bukan hal yang mudah untuk menyelenggarakan pemilihan yang demokratis. Pemerintah Kabupaten harus mampu memprediksikan dan memberikan solusi akan masalah-masalah yang bisa saja muncul dalam proses pemilihan mulai dari tahapan awal hingga akhir. Masalah itu bisa saja berupa rendahnya partisipasi masyarakat dalam pemilihan, kurang meratanya pengetahuan tentang aturan hukum dan terjadinya kecurangan diluar dari aturan perundang-undangan ataupun peraturan daerah.

Berdasarkan hasil penelitian dan didukung oleh berbagai fakta dilapangan, Pemilihan Kepala Desa serentak yang berlangsung di Kecamatan Parenggean dihadapkan pada berbagai fenomena, seperti aturan hukum yang belum mampu menjawab persoalan pemilihan, dan adanya gugatan masyarakat ataupun calon tentang ketidakpuasan hasil pemilihan.

\section{Metode Penelitian}

Pendekatan yang dilakukan dalam penelitian ini adalah pendekatan kualitatif. Pendekatan kualitatif ini bertujuan untuk mengungkap informasi kualitatif sehingga lebih menekankan pada masalah proses dan makna dengan cara mendeskripsikan permasalahan secara factual, sistematik dan akurat.

Melalui pendekatan kualitatif ini, data dan informasi diterjemahkan dan

\section{Jurnal Sociopolitico}


diinterpretasikan sedemikian rupa sehingga proses pemilihan kepala desa serentak di Kecamatan Parenggean dapat terlihat sebagaiaman mestinya.

\section{Hasil dan Pembahasan}

\section{Pelaksanaan Pemilihan Kepala Desa Bandar Agung Kecamatan Parenggean}

Jika dilihat dari prosedur atau tahapan pelaksanaan pemilihan makauntuk mengukur demokratis tidaknya pemilihan yang dilaksanakan oleh Pemerintah Daerah dapat dilihat dari tahpan-tahapannya. Tahapan yang dimaksud adalah tahapan persiapan, pencalonan, dan pemungutan suara. Untuk itu penulis akan uraikan secara detail pelakssanaan Pilkades di Desa Bandar Agung.

1) Tahapan Persiapan

a. Pemberitahuan BPD kepada Kepala

Desa tentang berakhirnya masa jabatan Kepala Desa.

1. BPD memberitahukan berakhirnya masa jabatan Kepala Desa 6 (enam) bulan sebelum berakhirnya masa jabatan Kepala Desa.

2. Kepala Desa mennyampaikan laporan penyelenggaraan pemerintahan Desa pada akhir masa jabatan secara tertulis kepada BPD dan Bupati paling lama 30 (tiga puluh) hari setelah pemberitahuan sebagaiamana dimaksud pada penjelasan sebelumnya.

3. Laporan penyelenggaraan Pemerintahan Desa sebagaimana dimaksud pada penjelasan kedua merupakan syarat administrasi bagi Kepala Desa yang akan mencalonkan diri pada periode berikutnya. b. Pembentukan Panitia Pelaksana Pemilihan Panitia pelaksana pemilihan Kepala Desa terdiri dari :

1. Panitia Pemilihan Kabupaten

a) Panitia pemilihan Kabupaten ditetapkan oleh Bupati dalam bentuk keputusan, paling lama 30 hari sejak terbentuknya panitia pemilihan tingkat desa.

b) Jumlah panitia pemilihan kabupaten sebagaiaman dimaksud disesuaikan dengan kebutuhan dan kemampuan keuangan daerah.

c) Panitia pemilihan kabupaten bertanggung jawab kepada bupati.

d) Tugas dan wewenang panitia pemilihan kabupaten, meliputi :

1. Merencanakan, mengkordinasikan dan menyelenggrakan semua tahapan pelaksanaan pemilihan tingkat kabupaten.

2. Melakukan bimbingan teknis pelaksanaan emilihan terhadap panitia pemilihan tingkat desa.

3. Melaksanakan ujian bakal calon.

4. Menetapkan jumlah surat suara dan kotak suara.

5. Memfasilitasi pencetakan surat suara dan pembuatan kotak suara serta perlengkapan pemilihan lainnya.

6. Menyampaikan surat suara dan kotak suara dan perlengkapan pemilihan lainnya kepa panitia pemilihan tingkat desa.

7. Memfasilitasi penyelesaian permasalahan pemilihan pada tingkat kabupaten.

8. Melakukan evaluasi dan pelaporan pelaksanaan pemilihan.

\section{Jurnal Sociopolitico}


9. Melaksanakan tugas dan wewenang lain yang ditetapkan

e) Ketentuan lebih lanjut mengenai pembentukan dan tugas kewenangan panitia pemilihan kabupaten diatur dalam peraturan bupati.

2. Panitia Pemilihan Tingkat Desa

a) Panitia pemilihan tingkat desa ditetapkan oleh BPD dalam bentuk keputusan, paling lama 10 (sepuluh) hari sejak pemberitahuan mengenai berakhirnya masa jabatan Kepala Desa.

b) Panitia Pemilihan Tingkat Desa berasal dari unsur Perangkat Desa, pengurus lembaga masyarakat desa dan tokoh masyarakat desa.

c) Susunan panitia pemilihan tingkat desa terdiri dari seorang ketua merangkap anggota, seorang sekretaris merangkap anggota, seorang bendahara merangkap anggota, dan beberaapa orang anggota.

d) Jumlah panitia pemilihan tingkat desa paling sedikit 5 orang dan paling banyak 7 orang.

e) Dalam hal pemilihan dilaksanakan lebih dari 1 (satu) TPS, maka panitia pemilihan tingkat desa dapat mengangkat ketua dan petugas TPS dalam bentuk surat keputusan.

f) Panitia pemilihan tingkat desa, ketua dan petugas TPS disampaikan secara tertulis oleh BPD kepada Bupati melalui Camat paling lama 7 (tujuh) hari sejak penetapannya.

g) Panitia pemilihan tingkat desa sebelum melaksanakan tugasnya terlebih dahulu menandatangani fakta integritas.

h) Dalam hal panitia pemilihan tingkat desa memiliki hubungan darah dengan calon maka BPD memberhentikan yang bersangkutan dan mengganti keanggotaannya yang ditetapkan dengan keputusan BPD.

i) Tugas dan wewnang Panitia pemilihan tingakat desa, meliputi :

1. Mengumumkan akan dilaksanakannya pemilihan sebelum berakhirnya maa jabatan Kepala Desa.

2. Merencanakan, mengkordinasikan, menyelenggarakan, mengawasi, dan mengendalikan semua tahapan pelaksanaan pemilihan.

3. Merencanakan dan mengajukan biaya pemilihan kepada Bupati melalui camat.

4. Melakukan pendaftaran dan penetapan pemilihan.

5. Mengadakan penjaringan dan penyaringan bakal calon.

6. Menetapkan calon yang telah memenuhi persyaratan.

7. Menetapkan tata cara pelaksanaan pemilihan.

8. Menetapkan nomor urut calon.

9. Menetapkan tempat, jadwal dan tata cara pelaksanaan kampanye.

10. Memfasilitasi penyediaan peralatan, perlengakpan dan TPS.

11. Melaksanakan pemungutan suara.

12. Mengambil keputusan apabila timbul permasalahan. 
13. Menetapkan hasil rekapitulasi perhitungan suara dan mengumumkan hasil pemilihan.

14. Menetappkan bakal calon dan calon terpilih.

15. Mangangkat dan menetapkan ketua dan petugas TPS.

16. Melakukan evaluasi dan pelaporan pelaksanaan pemilihan.

17. Mempersiapkan segala sesuatu yang berhubungan dengan pelaksanaan pemilihan.

j) Dalam melaksanakan tugas dan wewenangnya, panitia pemilihan tingkat desa wajib berlaku adil, jujur, transparan dan penuh tanggung jawab.

k) Panitia pemilihan tingkat desa bertanggung jawab kepada BPD.

c. Laporan akhir masa jabatan Kepala Desa kepada Bupati

d. Penyusunan jadwal proses pelaksanaan pemilihan

e. Penyusunan tata tertib pemilihan; dan

f. Penyusunan dan pengajuan rencana biaya pemilihan

Dari semua tahapan persiapan tersebut telah dilaksanakan sesuai dengan aturan yang berlaku, terkhusus untuk pembentukan panitia pemilihan, telah dibentuk panitia pemilihan tingkat desa. Panitia ini nantinya yang akan melaksanakan segala tahapan pemilihan yang bersifat teknis maupun non teknis pada tingkat desa. Panitia ini dibentuk atas inisiasi Badan Permusyawaratan Desa (BPD) bersama dengan tokoh-tokoh masyarakat.

Berikut nama-nama panitia pemilihan tingkat Desa Benteng Tellue yang telah ditetapkan dan dipilih berdasarkan kesepakatan dan aturan perundang-undangan.

Tabel 1

Nama-Nama Panitia Pemilihan Kepala Desa Bandar Agung

No Nama

1 Himam arsip udin Ketua

2 Sri wilasih Sekretaris

3 Mujiburohman Bendahara

4 Arifin Anggota

5 Parni Anggota

6 Heri Anggoro Anggota

Sumber: BPD (Surat Keputusan BPD

Tahun 2019 Tentang Pembentukan

Panitia Pemilihan Kepala Desa Bandar

Agung)

Sebelum penetuan dan penetapan panitia pemilihan, terlebih dahulu telah diadakannya rapat yang diprakarsai oleh Badan Permusyawaratan Desa dan diundang seluruh perangkat desa serta tokoh masyarakat. Diadakannya rapat sebagai upaya BPD agar nantinya terpilih panitia yang benar-benar netral dan menjalankan fungsinya dengan baik. Seperti yang diungkapkan Ketua BPD Desa Bandar Agung yakni:

"Saya selaku ketua BPD Desa Bandar Agung, melakukan rapat kemudian untuk menghasilkan kesepakatan, dan kebetulan anggota BPD di sini berjumlah 5 orang dengan mengundang unsurunsur masyarakat untuk di ikutkan dalam rapat hal membentuk panitia pemilihan, kami mengambil kesepakatan bahwa di Desa Bandar Agung ini terdapat 14 RT jadi wakil dari 14 RT itu masingmasing 1 orang dengan kriteria yang ada pada aturan daerah, dan rata-rata panitia kami itu sarjana. Yang saya tekankan bahwa mereka

\section{Jurnal Sociopolitico}


betul-betul menjalankan tugasnya sesuai dengan aturan, dengan artian harus bersifat netral." (Hasil Wawancara dengan Ketua BPD)

Sesuai dengan penjelasan Ketua BPD Desa Bandar Agung dan dibenarkan oleh ketua panitia pemilihan bahwa dalam penentuan panitia dilaksanakan secara musyawarah (rapat) dengan melibatkan berbagai unsur (perangkat Desa dan Tokoh Masyarakat). Dilibatkannya berbagai unsur dalam penentuan panitia pemilihan menggambarkan bahwa BPD telah menjalankan mekanisme pemilihan sesuai dengan aturan yang berlaku serta tak melupakan budaya musyawarah sesuai dengan tuntutan demokrasi.

\section{2) Tahapan Pencalonan}

Penjaringan Bakal Calon yang pelaksanaannya meliputi pengumuman dan penerimaan pendaftaran bakal calon;

a. Pengumuman dan Pendaftaran Bakal Calon

1. Pengumuman pendaftaran bakal calon dilaksanakan paling lama 3 (tiga) hari setelah pembentukan panitia pemilihan tingkat desa dan berakhir 1 (satu) hari sebelum pendaftaran dilaksanakan.

2. Pengumuman dilakukan dalam bentuk tertulis maupun lisan

3. Pengumuman dalam bentuk tertulis berisi batas waktu pendaftran dan persyaratan calon yang ditempelkan pada tempat-tempat yang mudah dilihat dan dibaca.

4. Pengumuman dalam bentuk lisan disampaikan ditempat-tempat umum dengan menjelaskan batas waktu pendaftaran dan syarat calon.
5. Pendaftaran bakal calon dilaksanakan oleh panitia pemilihan tingkat desa dalam waktu paling lama 9 (sembilan) hari.

6. Apabila waktu pendaftaran bakal calon telah berakhir dan bakal calon yang mendaftar hanya 1 (satu) orang, maka dilakukan perpanjangan waktu pendaftaran.

7. Perpanjangan waktu pendaftaran paling lama 7 (tujuh) hari.

8. Apabila perpanjangan waktu pendaftaran telah dilakukan dan jumlah bakal calon tetap 1 (satu) orang, maka pelaksanaan pemilihan ditunda dan dikelompokkan pada gelombang berikutnya.

9. Penundaan pemilihan dibuat dalam berita acara penundaan pemilihan.

10. Apabila penundaan pemilihan melewati akhir masa jabatan kepala desa, maka jabatan kepala desa dilaksanakan oleh pejabat kepala desa dari PNS.

b. Tata cara pendaftaran bakal calon :

1. Mengajukan surat permohonan pendaftaran bakal calon kepada bupati melaluli panitia pemilihan tingkat desa pada waktu dan tempat yang telah ditentukan.

2. Surat permohonan dibuat 4 (empat) rangkap dengan tulisan tangan yang ditandatangani dan dibubuhi materai $\mathrm{Rp}$ 6.000,00 (enam ribu rupiah).

3. Surat permohonan dilengakapidengan persyaratan calon.

4. Apabila pesyaratan calon belum lengkap atau atau tidak sempurna pada saat pendaftaran, maka permohonan pendaftaran bakal 
calon diberika waktu paling lama 3 (tiga) hari untuk melengkapi dan/atau menyempurnakannya.

5. Setiap pendaftaran bakal calon dan penyerahan kelengkapan dan/atau penyemournaan persyaratan calon diberikan bukti pendaftaran atau bukti penyerahan yang memuat jenis persyaratan yang telah diajukan.

6. Pendaftaran bakal calon dan penyerahan kelengkapan dan/atau penyempurnaan peryaratan calon dapat diwakilkan dengan memperlihatkan surat kuasa.

c. Penyaringan bakal calon yang pelaksanaannya meliputi penelitian, verifikasi, dan klarifikasi berkas administrasi syarat calon;

Penelitian syarat calon :

1. Panitia pemilihan tingkat desa melakukan penelitian terhadap persyaratan calon meliputi verifikasi dan klarifikasi kelengkapan dan keabsahan adminstrasi pencalonan dalam waktu paling lama 20 (dua puluh) hari.

2. Untuk kepentingan penelitian, panitia pemilihan tingkat desa dapat melakukan klarifikasi pada instansi yang terkait dengan mendapatkan surat keterangan dari instansi bersangkutan.

3. pabila bakal calon yang memenuhi persyaratan calon kurang dari 2 (dua) orang, maka panitia pemilihan tingkat desa mengumumkan dan memperpanjang waktu pendaftaran dalam penjaringan ulang paling lama 20 (dua puluh) hari.
4. Pelaksanaan pendaftaran ulang tidak termasuk bagi bakal calon yang dinyatakan memenuhi syarat.

5. Dalam hal bakal calon yang memenuhi persyaratan tetap kurang dari 2 (dua) orang, maka Bupati menunda pelaksanaan pemilihan sampai pada gelombang berikutnya.

d. Ujian bakal calon:

1. Ujian bakal calon dilaksanakan oleh panitia pemilihan tingkat kabupaten paling lama 3 (tiga) hari.

2. Ujian bakal calon dilaksanakan dalam bentuk ujian tertulis dan ujian lisan.

3. Hasil dari ujian bakal calon ditetapkan dalam suatu daftar nilai berdasarkan ranking nilai kumulatif yang diperoleh masingmasing bakal calon yang ditandatangani oleh panitia pemilihan kabupaten.

4. Hasil ujian bakal calon diserahkan kepada panitia pemilihan tingkat desa dalam keadaan tersegel paling lama 7 (tujuh) hari setelah ujian bakal calon dilaksanakan.

5. Ketentuan lebih lanjut mengenai pelaksanaan ujian bakal calon diatur dalam peraturan bupati.

e. Penetapan dan pengumuman calon;

Penetapan calon;

1. Bakal calon ditetapkan menjadi calon oleh panitia pemilihan tingkat desa dalam bentuk keputusan.

2. Calon yang ditetapkan paling sedikit 2 (orang) dan paling banyak 5 (lima) orang.

3. Calon tidak boleh mengundurkan diri sebagai calon. 
4. Panitia pemilihan tingakat desa mengumumkan calon mengumumkan calon kepada masyarakat baik lisan maupun

5. Tertulis pada ditempat-tempat yang terbuka sesuai dengan kondisi sosial budaya masyarakat setempat.

6. Dalam hal 2 (dua) calon yang ditetapkan, salah satunya meniggal dunia sebelum pencoblosan maka panitia pemilihan tingkat desa menunda pelaksaan proses pemilihan dengan membuat berita acara dan melaporkan kepada BPD untuk disampaikan kepada Bupati.

7. Dalam hal penundaan pelaksanaan proses pemilihan, Bupati menunda pelaksanaan pemilihan dan dimasukkan pada kelombang berikutnya.

f. Nomor urut calon:

1. Nomor urut calon ditentukan paling lama 2 (dua) hari sebelum kampanye dilaksanakan.

2. Penentuan nomor urut calon dilakukan dengan cara pencabutan nomor (sistem undi) yang telah disiapkan oleh panitia pemilihan tingkat desa.

3. Tatacara pelaksanaan pencabutan nomor urut calon di tentukan oleh pantia pemilihan tingkat desa secara terbuka dan tidak memihak.

4. Pelaksanaan pencabutan nomor urut dituangkan dalam berita cara dan hasilnya ditetapkan dengan keputusan panitia pemilihan tingkat desa.

5. Nomor urut calon yang telah ditetaapkan diumumkan disosialisakan oleh panitia pemilihan tingkat desa dan masingmasing calon.

g. Pendaftaran dan penetapan daftar pemilih;

1. Yang mempunyai hak untuk memilih adalah:

a) Warga Negara Republik Indonesia.

b) Bedomisili di desa yang bersangkutan sekurangkurangnya 6 (enam) bulan sebelum disahkannya daftar pemilih sementara yang dibuktikan dengan Kartu Tanda Penduduk atau surat keterangan penduduk dan kartu keluarga.

c) Pada hari pemungutan suara, sudah berumur 17 (tujuh belas) tahun atau sudah/pernah menikah.

d) Tidak sedang dicabut hak pilihnya berdasarkan putusan pengadilan yang berkekuatan hukum tetap.

e) Tidak sedang terganggu jiwa dan ingatannya.

2. Apabila terdapat lebih dari satu dokumen yang berbeda menerangkan usia dan/atau tanggal lahir pemilih maka yang diikuti adalah dokumen yang terbit terdahulu dan diterbitkan oleh instansi resmi.

3. Pemilih yang telah terdaftar dalam daftar pemilih ternyata tidak lagi memenuhi syarat, tidak dapat menggunakan hak memilih.

4. Pendaftaran pemilih dilaksanakan oleh panitia pemilihan tingkat desa dengan mendatangi rumah-rumah penduduk untuk mendaftarkan pemilih.

5. Pendaftaran pemilih dilaksanakan dengan mengelompokkan pemilih 
berdasarkan RT tempat tinggal pemilih.

6. Pemilih yang telah terdaftar dimutakhirkan dan di validasi oleh panitia pemilihan tingkat desa sesuai data penduduk di desa.

7. Pemutakhiran dilakukan berdasarkan pada:

a) Memenuhi syarat usia pemilih, yang sampai pada waktu pelaksanaan pemungutan suara sudah berumur 17 (tujuh belas) tahun.

b) Belum berumur 17 (tujuh belas) tahun, tetapi sudah/pernah menikah.

c) Telah meninggal dunia.

d) Pindah domisili ke desa lain.

e) Belum terdaftar sebagai penduduk pada desa yang bersangkutan.

f) RT tempat tinggal pemilih.

8. Berdasarkan daftar pemilih panitia peilihan tingkat desa menyusun nama pemilihan secara alfabetis pada masing-masing RT dan menetapkannya sebagai DPS.

9. DPS diumumkan paling lama 3 (tiga) hari dengan ditempelkan pada tempat-tempat yang terbuka agar dapat dilihat dan dibaca oleh pemilih atau masyarakat setiap RT yang bersangkutan.

10. Dalam jangak waktu pengumuman pemilih atau masyarakat umum dapat mengusulkan atau menginformasikan kepada panitia pemilihan tingkat desa agar dilakukan perbaikan pada DPS dalam hal :

a) Kesalahan penulisan nama atau identitas pemilih lainnya.

b) Pemilih yang terdaftar sudah meninggal dunia. c) Pemilih sudah tidak berdomisili di desa yang bersangkutan.

d) Pemilih yang sudah nikan dibawah umur 17 (tujuh belas) tahun.

e) Pemilih yang sudah terdaftar tetapi sudah tidak memenuhi syarat sebagai pemilih.

f) Pemilih yang terdaftar pada suatu RT bukan penduduk RT yang bersangkutan.

11. Apabila usul perbaikan dan informasi diterima, panitia pemilihan tingkat desa segera mengadakan perbaikan DPS sebagaimana mestinya.

12. Pemilih yang belum terdaftar dalam DPS, secara aktif melaporkan kepada panitia pemilihan tingkat desa secara langsung atau melalui kepala RT/pengurus rukun tangga/rukun warga.

13. Pemilih didaftar sebagai pemilih tambahan.

14. Pendaftaran pemilih tambahan dilaksanakan paling lama 3 (tiga) hari sejak waktu pengumuman DPS berakhir.

15. Pemilih tambahan ditetapkan oleh panitia pemilihan tingkat desa.

16. Daftar pemilih tambahan yang telah ditetapkan, diumumkan oleh panitia pemiliha tingkat desa dengan menempelkan nama- nama pemilih pada tempat-tempat yang mudah dilihat dan dibaca oleh masyarakat pada setiap RT.

17. Waktu pengumuman daftar pemilih tambahan, dilaksanakan paling lama 3 (tiga) hari terhitung sejak berkhirnya jangka waktu pendaftaran pemilih tambahan. 
18. Panitia pemilihan tingkat desa menetapkan dan mengumumkan DPS yang sudah diperbaiki dan daftar pemilih tambahan sebagai DPT.

19. DPT diumumkan dengan menempelkan nama-nama pemilih pada tempat-tempat yang startegis pada setiap RT untuk diketahui oleh masyarakat pada RT yang bersangkutan.

20. Jangka waktu pengumuman DPT paling lama 3 (tiga) hari sejak ditetapkannya DPT.

21. DPT tidak dapat diubah, kecuali terdapat pemilih yang meninggal dunia, maka panitia pemilihan tingkat desa membutuhkan catatan pada kolom keterangan dalam DPT dengan tulisan "Meninggal Dunia".

22. Panitia pemilihan tingkat desa memberikan surat panggilan kepada pemilih yang terdaftar dalam DPT dengan tanda terima paling lama 1 (satu) hari sebelum hari pemungutan suara.

23. Pemilih yang belum menerima surat panggilan dapat meminta kepada panitia pemilihan tingkat desa paling lama 2 (dua) jam sebelum pemilihan calon dilaksanakan.

24. Apabila surat panggilan hilang, maka pemilih dapat meminta pengganti dengan mengisi blanko yang disediakan panitia pemilihan tingkat desa.

25. Surat panggilan digunakan pemilih untuk mendapatkan surat suara pada hari pemungutan suara yang telah ditentukan.

26. Dalam hal pemilih yang telah terdaftar dalam DPT tidak mendapatkan surat panggilan, pemilih yang bersangkutan dapat mempergunakan hak pilihnya dengan memperlihatkan Kartu Tanda Penduduk dan/atau Kart Keluarga yang masih berlaku.

h. Pelaksanaan kampanye calon

1. Kampanye dilaksanakan dengan prinsip jujur, terbuka dan bertanggung jawab serta sesuai dengan kondisi sosial budaya masyarakat Desa.

2. Kampanye dilaksanakan paling lama 3 (tiga) hari dan berakhir sebelum dimulainya masa tenang.

3. Setiap calon wajib menyampaikan tim kampanye kepada panitia pemilihan tingkat desa paling lambat 1 (satu) hari sebelum kampanye dimulai.

4. Pelaksanaan kampanye pada hari pertama diselenggarakan secara terpadu oleh panitia pemilihantingkat desa untuk mendengarkan visi dan misi masing-masing calon.

5. Visi merupakan keinginan yang ingin diwujudkan dalam jangka waktu masa jabatan Kepala Desa.

6. Misi merupakan program yang ingin dilaksanakan dalam rangka mewujudkan visi calon.

7. Tata cara pelaksanaan kampanye ditetapkan oleh panitia pemilihan tingkat desa dalam tata tertib kampanye.

8. Setiapcalon dapat melakukan kampanye dalam waktu yang telah ditentukan, dengan cara:

a) Pertemuan terbatas

b) Tatap muka

c) Dialog

d) Penyebaran bahan kampanye kepada umum 
e) Pemasangan alat peraga ditempat kampanye dan ditempat lain yang telah ditentukan oleh Panitia Pemilihan Tingkat Desa

f) Kegiatan lain yang tidak melanggar peraturan perundang-undangan.

9. Setiap calon wajib memperhatikan dan menjaga etika, estetika dalam pelaksanaan kampanye.

10. Pelaksanaan waktu dan tempat kampanye diatur secara adil dan merata oleh Panitia Pemilihan Tingkat Desa dengan mempertimbangkan usul dan saran para calon.

11. Setiap calon dan pelaksanaan kampanye, dilarang melakukan sikap, tindakan dan ucapan, sebagai berikut:

a) Mempersoalkan dasar Negara Pancasila, Pembukaan Undangundang Dasar Negara Republik Indonesia Tahun 1945 dan bentuk Negara Kesatuan Republik Indonesia.

b) Melakukan kegiatan yang membahayakan keutuhan Negara Kesatuan Republik Indonesia.

c) Menghina seseorang, agama, suku, ras, golongan, calon dan/atau calon yang lain

d) Menghasut dan mengadu domba perseorangan atau masyarakat

e) Mengganggu ketertiban umum

f) Mengancam untuk melakukan kekerasan atau menganjurkan penggunaan kekerasan kepada seseorang, sekelompok anggota masyarakat dan/atau calon yang lain
g) Merusak dan/atau menghilangkan alat peraga kampanye calon

h) Menggunakan fasilitas pemerintah, tempat ibadah dan tempat pendidikan.

i) Membawa atau menggunakan gambar dan/atau atribut calon lain selain dari gambar dan/atau atribut calon yang bersangkutan

j) Menjanjikan atau memberikan uang atau materi lainnya kepada peserta kampanye.

12. Selain larangan calon dan pelaksanaan kampanye dalam kegiatan kampanye dilarang mengikutsertakan:
a) Kepala Desa
b) Perangkat Desa
c) Anggota Badan Permusyaratan Desa.

i. Masa tenang

1. Masa tenang dilakukan paling lama 3 (tiga) hari dimulai setelah berakhirnya waktu kampanye sampai dimulainya hari pemungutan suara.

2. Setiap calon atau tim kampanye calon dilarang melakukan aktifitas kampanye atau kegiatan dalam bentuk apapun dengan maksud mempengaruhi atau mengarahkan pemilih pada masa tenang.

Pada tahapan ini panitia pemilihan membuka pendaftaran bagi masyarakat yang ingin mendaftar sebagai bakal calon Kepala Desa. Bakal Calon Kepala Desa harus melalui verifikasi berkas dan ujian bakal calon yang telah diatur mekanismenya oleh panitia. Untuk verifikasi bakal calon pani tia pemilihan tingkat desa diberikan kepercayaan untuk menjaring bakal calon dari sisi 
kelengkapan adminstratifnya apakah telah sesuai dengan persyaratan atau belum. Sementara untuk ujian bakal calon menjadi calon menjadi tanggung jawab dan diselenggarakan panitia tingkat Kabupaten. Berikut nama-nama bakal calon yang telah dinyatakan lulus pada tahap verifikasi berkas.

\section{Tabel 2}

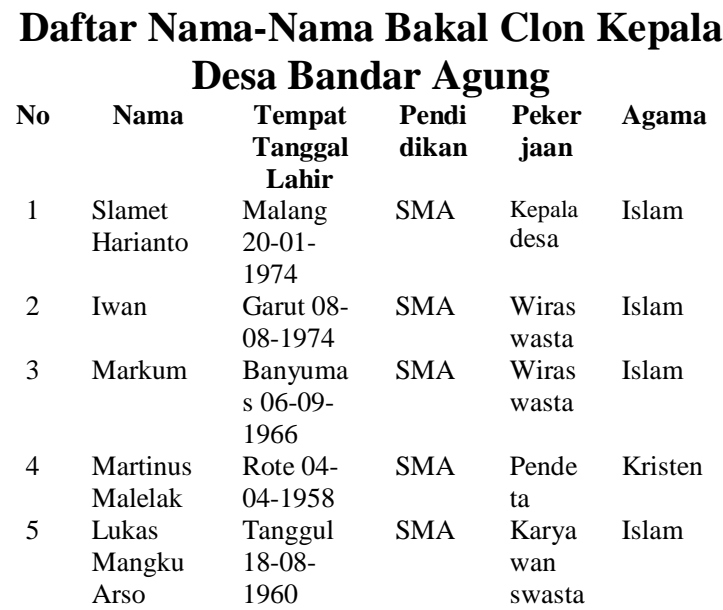

Sumber: Dokumen Pemilihan (Berita Acara Penyempurnaan Persyaratan Bakal Calon Kepala Desa Bandar Agung)

Dari daftar bakal calon yang lulus verfikasi berkas seperti yang terlihat pada tabel diatas, semua telah lulus ujian seleksi di kabupaten yang diselenggarakan oleh panitia tingkat kabupaten.

Asumsi banyak orang bahwa dalam penjaringan calon kepala desa hanya sebatas prosedural semata, karena tidak mempertimbangkan kompetensi calon, berbeda dengan penjaringan calon legislatif ataupun calon kepala daerah yang betul-betul dilakukan penyeleksian sesuai dengan kompetensi mereka. Namun pemahaman banyak orang ternyata tidak terbukti, ini terlihat di desa Bandar Agung yang setelah terpilihnya sebagai Kepala Desa ia dilaporkan menggunakan ijazah palsu, tetapi panitia pemilihan tingkat desa telah membuktikan bahwa ijazah yang di gunakan itu telah dilegalisir oleh instansi tersebut, seperti yang di ungkapkan oleh Ketua Panitia Pemilihan Tingkat Desa Bandar Agung, yaitu:

"dalam Undang-Undang itu tentang persyaratan calon, apabila dia sudah memiliki foto copy ijazah yang sudah dilegalisir oleh pejabat yang berwenang, maka itu yang akan dikelola. Apabila tidak ada yang diatur diperda otomatis dia terkendala di panitia, tetapi kesemua faktor pendukung ini ada semua".(Hasil Wawancara dengan Ketua Panitia)

Dengan pernyataan diaatas bahwa panitia pemilihan tingkat desa telah melakukan tugasnya sesuai dengan prosedural yang ada, senada yang disampaikan oleh Bapak Sekretaris Panitia Pemilihan Kepala Desa yaitu:

"kita sebagai panitia hanya menyeleksi kelengkapan dari pada calon yang berkasnya, berkas calon diseleksi apabila ada yang dianggap tidak memenuhi syarat maka kita akan batalkan, tetapi apa yang mereka ajukan semua memenuhi syarat, foto copy ijazahnya dilegalisasi oleh pejabat yang berwenang, kemudian semua kelengkapan-kelengkapan

berkasnya seperti SKCK nya dan keterangan penduduknya semua memenuhi syarat, jadi kita loloskan, setelah ada laporan setelah dia terpilih dan ketentuannya bahwa paling lama 1 (satu) bulan dinyatakan terpilih harus dilantik, kalau ada proses hukum silahkan diproses nanti setelah ikrar, kalau memang terbukti diberhentikan, baru

\section{Jurnal Sociopolitico}


dilakukan pemilihan ulang, tetapi sampai saat ini belum ada pembuktian bahwa ijzahnya itu palsu, hanya laporannya bahwa menggunakan ijazah palsu, tapi setelah diproses secara hukum tidak bisa dibuktikan"(Hasil Wawancara dengan Sek. Panitia).

3) Tahap Pemungutan Suara

a. Pelaksanaan pemungutan suara dan perhitungan surat suara

1. Waktu, tempat dan peralatan pemungutan suara:

a) Pemungutan suara dilaksanakan pada hari tanggal yang telah ditentukan oleh Bupati

b) Waktu pelaksanaan pemungutan suara dimulai pada pukul 07.00 sampai dengan 13.00 Waktu Indonesia Barat

c) Pemungutan suara dilaksanakan di TPS yang ditentukan dan dipersiapkan oleh Panitia Pemilihan Tingkat Desa.

d) TPS dapat dibuat pada disetiap RT untuk penduduk RT yang bersangkutan atau 1 (satu) TPS gabungan RT atau lebih dari 1 (satu) TPS gabungan RT bagi pemilih dari beberapa RT dengan menempatkannya pada lokasi yang mudah dijangkau oleh pemilih dari RT yang bersangkutan.

e) Peralatan pemungutan suara dipersiapkan oleh Panitia Pemilihan Kabupaten

f) Peralatan sudah berada ditempat pemilihan sebelum pemungutan

suara dilaksanakan.

2. Pelaksanaan Pemungutan Suara

a) Pada saat pemungutan suara dilaksanakan, setiap calon berhak berada ditempat yang disediakan oleh Panitia Pemilihan Tingkat Desa.

b) Dalam hal calon tidak hadir dalam pemilihan, digantikan dengan menempelkan foto dan nomor urut calon pada kursi yang dipersiapkan untuk calon.

c) Setiap calon dapat menugaskan saksi dengan surat mandat untuk menghadiri dan menyaksikan jalannya pemungutan dan perhitungan surat suara.

d) Surat mandat saksi calon diserahkan kepada Panitia Pemilihan Tingkat Desa paling lambat 1 ( satu) hari sebelum pemungutan suara dilakasanakan.

e) Saksi calon berhak mengajukan pertanyaan, kebertan dan penolakan dalam memberikan persetujuan untuk mewakili kepentingan calon berkaitan dengan pelaksanaan pemungutan suara dan perhitungan surat suara.

f) Saksi calon ditempatkan pada tempat yang mudah memantau jalannya pemungutan dan perhitungan surat suara.

g) Sebelum melaksanakan pemungutan suara, Panitia Pemilihan Tingkat Desa melakukan kegiatan:

1) Mengundang saksi dan mempersilahkan saksi menempati tempat yang telah disiapkan oleh Panitia Pemilihan Kepala Desa

\section{Jurnal Sociopolitico}


2) Membuka dan pengeluaran seluruh isi kotak suara

3) Mengidentifikasi jenis dan menghitung jumlah setiap jenis dokumen dan peralatan

4) Memberikan penjelasan mengenai tata cara pemungutan suara, dan

5) Menunjukkan kotak suara sebagai tempat penyimpanan hasil coblosan.

h) Kotak suara yang tela terbuka dan dikeluarkan isinya, kembali ditutup, dikunci dan disegel dengan kertas yang telah dibubuhi cap stempel Panitia Pemilihan Tingkat Desa dalam keadaan kosong setelah meyakinkan kepada calon/saksi, pemilih, BPD, dan Pengawas.

i) Kegiatan Panitia Pemilihan Tingkat Desa dibuatkan berita acara yang ditandatangani oleh Ketua Panitia Pemilihan Tingkat Desa atau ketua TPS atau yang mewakili bersama dengan sekurang-kurangnya 2 (dua) anggota Panitia Pemilihan Tingkat Desa, serta dapat ditandatangani oleh saksi dari calon.

j) Selama pelaksanaan pemungutan suara berlangsung, anak kunci kotak suara dipegang Ketua Panitia Pemilihan Tingkat Desa atau Ketua TPS atau yang mewakili.

k) Pemilih yang hadir diberikan selembar surat suara oleh Panitia Pemilihan Tingkat Desa melalui pemanggilan berdasarkan urutan daftar hadir dengan menyebutkan Dusun Pemilih.

1) Pemilih memeriksa atau meneliti surat suara dan apabila surat suara dimaksud dalam keadaan cacat atau rusak, Panitia Pemilihan Tingkat Desa mengganti dengan surat suara yang baru.

m) Pemilih memberikan suara melalui surat suara dalam bilik suara dengan menggunakan alat yang disediakan oleh Panitia Pemilihan Tingkat Desa.

n) Pemberian suara dilakukan dengan cara mencoblos nama, foto atau ruang dalam kotak calon yang terdapat dalam surat suara.

o) Pemilih yang keliru mencoblos surat suara dapat meminta pergantian surat suara setelah menyerahkan surat suara yang keliru dicoblos kepada Panitia Pemilihan Tingkat Desa.

p) Pergantian surat suara hanya 1 (satu) kali.

q) Surat suara yang telah tercoblos pemilih memasukannya

r) kedalam kotak suara yang disediakan dalam keadaan terlipat.

s) Setiap pemilih tidak dapat diwakili atau dibantu untuk

t) mencoblos surat suara dengan alasan apapun, kecuali cacat fisik karena atas permintaannya sendiri.

u) Anggota Panitia Pemilihan Tingkat Desa atau orang lain yang membantu pemilih wajib merahasiakan pilihan pemilih yang bersangkutan.

v) Dalam hal pemilih sakit atau sedang menjalani hukuman penjara yang membuatrnya tidak dapat mendatangi TPS dapat memberikan suara pada TPS khusus berdasarkan kesepakatan Panitia Pemilihan Tingkat Desa dan seluruh saksi atau calon.

3. Quorum Pemungutan Suara

\section{Jurnal Sociopolitico}


a) Pemungutan suara dinyatakan quorum apabila dihadiri pemilih yang menggunakan hak pilihnya sekurang-kurangnya $1 / 2$ (seperdua) ditambah 1 (satu) dari jumlah DPT yang telah dutetapkan Panitia Pemilihan Tingkat Desa.

b) Apabila quorum belum tercapai, maka waktu pemungutan suara diperpanjang paling lama 1 (satu) jam.

c) Apabila perpanjangan waktu telah dilakukan dan quorum belum tercapai, maka Panitia Pemilihan Tingkat Desa tetap melanjutkan penghitungan suara dan hasilnya dinyatakan sah serta dimuat dalam berita acara pelaksanaan.

4. Penghitungan Surat Suara dan Pengumuman Calon Terpilih

a) Penghitungan surat suara dilaksanakan oleh Panitia Pemilihan Tingkat Desa pada saat berakhirnya waktu pemungutan suara.

b) Dalam hal pemilihan dilaksanakan dengan TPS gabungan dusun, penghitungan surat suara dilaksanakan tersendiri dan terpisah dengan masing-masing dusun.

c) Penghitungan surat suara dilaksanakan dengan cara:

1) Pantia Pemilihan Tingkat Desa memeriksa keadaan kotak suara serta membuka dan memulai penghitungan surat suara.

2) Setiap lembar surat suara dari dalam kotak suara diperlihatkan kepada saksi dan diteliti satu demi satu untuk mengetahui kondisi sur4at suara dan suara yang diberikan kepada calon.
3) Menyebutkan nomor urut yang tercoblos dalam surat suara dan mencatatnya dipapan tulis yang ditempatkan sedemikian rupa, sehingga dapat dilihat dengan jelas oleh semua saksi yang hadir

4) Surat suara yang telah dihitung dimasukkan kedalam kotak suara.

d) Sebelum penghitungan suara dimulai, Pantia Pemilihan Tingkat Desa menghitung secara umum:

1) Jumlah pemilih yang memberikan suara berdasarkan salinan daftar pemilih tetap pada TPS yang bersangkutan

2) Jumlah surat suara yang tidak terpakai.

3) Jumlah surat suara yang dikembalikan oleh pemilih karena rusak atau keliru dicoblos.

e) Perhitungan surat suara harus seslesai di TPS pada hari pelaksanaan pemungutan suara dengan disaksikan oleh saksi calon, BPD, Pengawas dan Warga Masyarakat.

f) Surat suara dianggap sah apabila:

1) Menggunakan surat suara yang telah ditetapkan

2) Surat suara ditandatangani oleh ketua Panitia Pemilihan Tingkat Desa atau ketua TPS atau yang mewakili masingmasing

3) Tidak terdapat tambahan tulisan atau tanda-tanda lain selain yang telah ditetapkan

4) Tanda coblos hanya terdapat pada 1(satu) kotak segi empat yang memuat satu calon 
5) Tanda coblos terdapat dalam salah satu kotak atau segi empat yang memuat nomor, foto dan nama calon yang telah ditentukan

6) Tanda coblos lebih dari satu, tetapi masih didalam satu kotak segi empat yang memuat nomor, foto, dan nama calon.

7) Surat suara tidak rusak dan/atau tidak berubah bentuk

8) Menggunakan alat pencobos yang disiapkan Panitia Pemilihan Tingkat Desa.

g) Dalam hal terjadi perbedaan pendapat mengenai sah atau tidakanya coblosan surat suara, Panitia Pemilihan Tingkat Desa berkewajiban memberikan keputusan berdasarkan musyawarah mufakat dengan saksi-saksi calon.

h) Keputusan Panitia Pemilihan Kepala Desa dituangkan dalam berita acara pemilihan calon.

i) Setelah perhitungan suara selesai, Panitia Pemilihan Tingkat Desa membuat berita acara penghitungan suara yang ditandatangani oleh ketua dan sekurang-kurangnya 2 (dua) orang anggota Panitia Pemilihan Tingkat Desa serta dapat ditandatangani oleh saksi atau calon.

j) Berita acara dimasukkan dalam sampul khusu yang disediakan Panitia Pemilihan Tingkat Desa untuk:

1) Sebanyak 1 (satu) eksemplar diberikan kepada masingmasing saksi atau calon yang hadir.

2) Sebanyak 1 (satu) eksamplar disimpan dalam kotak suara bersama dengan surat suara, dokumen administrasi dan peralatan pemungutan suara lainnya

3) Sebanyak 1 (satu) eksamplar ditempelkan pada tempat umum.

k) Panitia pemilhan menyerahkan berita acaraa hasil penghitungan suara, surat suara dan alat kelengkapan administrasi pemungutan dan penghitungan suara kepada BPD segera setelah selesai penghitungan suara.

1) Perlengkapan pemungutan suara dan penghitungan suara di TPS, disimpan dikantor Desa atau ditempat lai $\mathrm{n}$ yang terjamin keamanannya.

b. Pengumuman Penetapan Calon Terpilih Secara Lisan

1. Penetapan calon terpilih

a) Calon Kepala Desa yang memperoleh suara terbanyak dari jumlah suara sah ditetapkan sebagai Calon Kepala Desa Terpilih.

b) Dalam hal jumlah calon Kepala Desa terpilih yang memperleh suara terbanyak sama lebih dari 1 (satu), calon terpilih ditetapkan berdasarkan suara terbanyak pada TPS dengn jumlah pemilih terbanyak.

c) Dalam hal jumlah calon terpilih yang memperoleh suara terbanyak yang sama lebih dari 1 (satu) calon pada Desa dengan TPD hanya 1 (satu), calon terpilih ditetapkan berdasarkan wilayah tempat tinggal dengan jumlah pemilih terbesar.

d) Dalam hal jumlah calon terpilih yang memperoleh suara terbanyak yang sama lebih dari 1 (satu) calon 
pada dusun yang sama dengan 1 (satu) TPS atau lebih dari 1 (satu) TPS maka calon terpilih adalah calon yang memiliki tingkat pendidikan yang lebih tinggi.

e) Dalam hal tingkat pendidikan sama maka calon terpilih adalah calon yang memperoleh nilai tertinggi berdasarkan hasil ujian bakal calon.

2. Pelaporan dan Pengesahan

a) Pantia Pemilihan Tingkat Desa melaporkan calon terpilih kepada BPD dengan tembusan kepada Camat palign lama 7 (tujuh) hari setelah pemungutan suara.

b) BPD melaporkan calon terpilih kepada Bupati melalui Camat paling lama 7 (tujuh) hari setelah menerima laporan dari Panitia Pemilihan Tingkat Desa.

c) Laporan BPD sekaligus sebagai permohonan pengesahan dan pengangkatan calon terpilih menjadi Kepala Desa, kepada Bupati.

d) Pengesahan dan pengangkatan Kepala Desa ditetapkan dalam bentuk keputusan Bupati.

e) Keputusan diterbitkan paling lama 30 (tiga puluh) hari sejak diterimanya laporan dari BPD.

Pemberian suara dalam pemilu merupakan wujud partisipasi dalam politik, kegiatan ini tidak sekedar hanya pemilihan memberikan suaranya namun sebelumnya terdapat rangkaian proses mengapa seseorang memutuskan untuk berangkat ke TPS atau tidak. Pada tahapan ini, mekanisme pemungutan suara dilaksanakan dan diatur di tempat pemungutan suara (TPS). Pemungutan dan perhitungan suara adalah peristiwa paling menentukan apakah calon terpilih sebagai
Kepala Desa ataupun gagal bedasarkan suara yang diberikan oleh masyarakat desa yang mempunyai hak pilih. Untuk menilai sejauh mana keberhasilan pelaksanaan pemungutan hingga perhitungan suara dapat dilihat dari kondisi TPS yang baik dan aman, pemungutan suara dilaksanakan dengan aman dan tertib serta perhitungan suara dilaksanakan secara terbuka dan jujur, juga tingkat partisipasi masyarakat tinggi.

Menurut Kepala Desa terpilih Bandar Agung Slamet Harianto mengungkapkan bahwa :

"Pelaksanaan pilkades menurut saya sudah bagus tidak ada yang ditemukan kecurangan, semuanya berjalan sesuai dengan aturan, semua itu karena kesiapan panitia pemilihan, dan saya melihat antusias masyarakat untuk memilih Kepala Desa sasuai dengan hatinya tidak ada introfensi dari pihak manapun, sehingga pemilihan kemarin sudah saya anggap demokratis."(Hasil wawancara dengan Kades).

Pernyataan kepala desa terpilih melihat bahwa masyarakat sudah mengenal yang namanya berdemokrasi. Msyarakat kemudian mulai sadar dengan memilih pemimpin mereka sesuai dengan hati nuraninya, tanpa harus tertekan oleh kelompok tertentu. Hal yang sama juga dikatakan oleh tokoh masyarakat, yang mengemukakan bahwa:

"Proses pemungutan suara berjalan dengan lancar sesuai apa yang telah diaturkan, masyarakat berbondong-bondong datang ke TPS sampai pas pukul 12 hampir semua memberikan hak suaranya

\section{Jurnal Sociopolitico}


sekitar 800-an yang hadir"(Hasil Wawancara dengan Tokoh Masyarakat).

Selain dari pelaksanaan pemungutan suara di TPS berjalan dengan aman dan tertib. Salah satu indikator demokratis tidaknya pemilihan adalah netralitas dari panitia pemilihan, dilihat dari bagaimana mereka menjalankan fungsinya sesuai dengan aturan. Sehingga segala bentuk dokumen pemilihan harus ditransparankan ke wajib pilih. Pelaksanaan Pilkadesa di Desa Bandar Agung sendiri berdasarkan kalkulasi dari panitia pemungutan suara di TPS telah didapatkan wajib pilih yang menggunakan hak pilihnya dengan rincian surat suara sebagai berikut:

\section{Tabel 3}

\section{Hasil Pelaksanaan Pemungutan Suara Kepala Desa Bandar Agung}

Jumlah pemilih dalam daftar 797 pemilih tetap

Jumlah pemilih yang datang

menggunakan hak pilih

Jumlah pemilih yang tidak

datang menggunakan hak pilih

Jumlah surat suara

Surat suara yang diberikan

kepada pemilih

Jumlah surat suara yang

dimasukan ke kotak suara

Jumlah surat suara yang

dinyatakan tidak sah

Jumlah surat suara yang

dinyatakan sah

Sumber : Dokumen Pemilihan (Berita Acara Pelaksanaan Pemilihan Kepala Desa Bandar Agung)

Dari rincian surat suara tersebut kemudian diumumkan langsung ditempat pemungutan suara dengan disaksikan oleh calon Kepala Desa yang berhak dipilih dan saksi, serta warga masyarakat ditempat pemilihan.

Berdasarkan tabel diatas dari hasil perhitungan suara sah, masing-masing calon memperoleh suara sebagai berikut :

\section{Tabel 4}

\begin{tabular}{clc}
\multicolumn{2}{c}{$\begin{array}{c}\text { Perolehan Suara Masing-Masing Calon } \\
\text { Kepala Desa Bandar Agung }\end{array}$} \\
No & \multicolumn{1}{c}{ Nama Calon } & $\begin{array}{c}\text { Jumlah } \\
\text { Suara }\end{array}$ \\
& & 286 \\
1 & Slamet Harianto & 103 \\
2 & Iwan & 135 \\
3 & Markum & 87 \\
4 & Martinus Malelak & 197 \\
5 & Lukas Mangku Arso & 808
\end{tabular}

Sumber : Dokumen Pemilihan (Berita Acara Pelaksanaan Pemilihan Kepala Desa Benteng Tellue)

Dari hasil perolehan suara merujuk pada hasil suara terbanyak, pemilihan Kepala Desa Benteng Tellue dimenangkan oleh calon nomor urut satu (1), denga perolehan 286 suara. Jika dihitung dari jumlah surat suara yang dinyatakan sah 808 suara berarti dukungan masyarakat Bandar Agung yang memilih calon nomor urut satu sekitar 35,39\%. Sementara tingkat partisipasi masyarakat atau yang menggunakan hak pilih terhitung dari daftar pemilih tetap berarti partisipasi masyarakat sekitar 98,6\%. Angka ini sudah cukup mapan jika dibenturkan pada kesadaran masyarakaat dalam memilih pemimpin mereka, serta kompetisi antar calon yang berjalan tertib.

Hasil pemilihan ini berarti Desa Bandar Agung telah memiliki nahkoda baru dalam menjalankan roda pemerintahan. Jika pra pemilihan hingga

\section{Jurnal Sociopolitico}


hari pemungutan suara iklim kompetisi antar calon sangat terasa, dan yang ditakutkan adalah, masyarakat kemudian akan terpecah dalam beberapa kelompok pasca pemilihan karena fantisme mereka akan calonnya masing-masing. Tetapi wajah berbeda diperlihatkan oleh Desa Bandar Agung yang menanggapi sangat dewasa hasil pemilihan, dibuktikan dari hal -hal yang ditakutkan seperti akan ada sekat-sekat antar kelompok masyarakat nyatanya tidak terjadi. Seperti yang ungkapakan oleh Kepala Desa terpilih Slamet Harianto mengatakan bahwa:

"dari pemilihan kemarin saya anggap berhasil, karen pasca pemilihan masyarakat menerima hasil pemungutan suara, begitu pula dengan calon lain, dengan basis memiliki suara di RT lain, dan tidak menyaka bahwa di RT tersebut sangat ramah" (Hasil wawancara dengan Kades)

Hal senada juga dikatan oleh calon yang tidak terpilih Markum, menerangkan bahwa :

"Dalam pelaksanaan pemilihan kemarin saya menganggap itu sebuah berhasil, melihat antusias masyarakat menerima hasil pemilihan, dan saya sebagai calon yang tidak terpilihpun menerima hasil yang diberikan, karena berkat ketidak adanya kecurangan, dan transparansi dari panitia, mau tidak mau saya harus terima." (Hasil wawancara dengan calon Kades)

Dari hasil pemilihan di Desa Bandar Agung memperlihatkan kedewasaan para calon dan pemilih. Calon yang kalah betul -betul mengakui kekalahannya dan masyarakat yang calonnya tidak terpilih juga sadar bahwa dalam kompetisi ada menang dan ada kalah, sehingga hasil pemilihan tidak membuat masyarakat untuk tidak mengakui Kepala Desa terpilih. Pasca pemilihanpun masyarakat sudah tidak adanya kelompok dari masing-masing calon dan segera melebur kembali dalam membangun Desa mereka.

Panitia pemilhan tingkat desa telah melakukan verifikasi berkas terhadap kepala desa Bandar Agung sesuai dengan yang diatur dalam peraturan tentang persyaratan calon, dimana apabila ia telah memiliki foto copy ijazah yang sudah dilegalisir oleh pejabat yang berwenang, maka panitia pemilihan tingkat desa akan mengelola berkas kepala desa tesebut, karena dianggap telah memenuhi persyaratan. Apabila hal tersebut tidak diatur di dalam peraturan maka ia akan terkendala di pantia pemilihan tingkat desa.

\section{Faktor Yang Mempengaruhi Pelaksanaan Pilkades Di Desa Bandar Agung}

Selama Pelaksanaan pemilihan Kepala Desa serentak tentunya banyak faktor yang mempengaruhi. Faktor tersebut tentunya akan mempengaruhi keberlangsungan pemilihan mulai dari tahapan awal hingga ditetapkannya calon terpilih. Dalam melahirkan pemilihan yang demokratis tidak serta merta terjadi begitu saja tetapi ada beberapa faktor yang mempengaruhinya. Adapun faktor-faktor yang mempengaruhinya adalah sebagai berikut:

a) Ketidakjelasan persyaratan calon

Dalam menentukan persyaratan kedepannya harus di perjelas lagi baik ijazah apakah wajib harus dilegalisir oleh pejabat yang berwenang. Panitia dapat

\section{Jurnal Sociopolitico}


menjelaskan persyaratan secara rinci agar para calon kades dapat mempersiapakan syaratnya yang diperlukan, jangka waktu penerimaan dapat dipertimbangkan juga agar dalam persiapan berkas dapat mendapatkan waktu yang cukup.

b) Kurang telitinya panitia pemelihan tingkat desa dalam memverifikasi berkas calon.

Kurang telitinya panitia pemelihan tingkat desa dalam memverifikasi berkas calon sehingga terjadi penggunaan ijazah palsu dapat menjadi persolan dikemudian hari, panitia agar lebik selektif dalam memverifikasi berkas yang masuk kepada panitia. Karena dalam pemilihanlah kita bisa melahirkan seorang pemimpin yang betul-betul pemimpin yang dapat membangun desanya menuju lebih baik lagi, serta mensejahterahkan rakyatnya yang jujur dan adil.

Solusi dalam hal ini Penyelenggaraan Pemilihan Kepala Desa serentak yaitu adanya tim independen, yang terlepas dari pemerintah daerah dan terlepas dari pemerintah desa maupun pemerintah Kabupaten. Seperti KPU (Komisi Pemilihan Umum), ada baiknya kepala desa diberikan kepada KPU (Komisi Pemilihan Umum, karena ia memiliki Kepanitiaan sendiri dan lebih berpengalaman dalam pemilihan, serta KPU (Komisi Pemilihan Umum) lebih independen dalam pelaksanaannya, sehingga dalam pelaksanaan pemilihan lebih baik lagi.

\section{Kesimpulan}

1. Pelaksanaan Pemilihan Kepala Desa Serentak di Desa Bandar Agung dimulai dari tahapan Persiapan, Pencalonan hingga pemungutan suara dapat penulis simpulkan bahwa telah berjalan sesuai dengan prosedur tetapi harus lebih teliti lagi dalam melakukan pemeriksaan terhadap persyaratan calon yang meliputi verifikasi dan klarifikasi kelengkapan dan keabsahan administrasi pencalonan

Pada tahapan persiapan panitia pemilihan telah dimusyawarakan bersama seluruh elemen desa. Pada tahap pencalonan panitia membuka peluang bagi seluruh masyarakat yang telah memenuhi syarat serta melakukan penjaringan verifikasi berkas dan ujian tertulis. Pada tahapan pemungutan suara berjalan dengan aman dan lancar serta masyarakat yang menggunaka hak suaranya $\pm 98,6 \%$. Angka yang baik jika diukur dari tingkat partisipasi masyarakat dalam memilih pemimpin Desa.

2. Adapun Faktor yang mempengaruhi jalannya pelaksanaan Pemilihan Kepala Desa serentak adalah Pertama, ketidak jelasan tentang persyaratan ijazah bagi calon. Kedua, Kurang telitinya panitia pemelihan tingkat desa dalam memverifikasi berkas calon.

\section{Referensi}

Budiardjo, Miriam. 2010. Dasar-Dasar Ilmu Poltik. Jakarta: PT Gramedia Pustaka Utama. Jakarta.

Daniel Sparringga. 2009. Politik dan Pemerintahan Indonesia: Demokrasi, Perkembangan Sejarah Konsep dan Praktiknya. MIPI. Jakarta.

Djam'an, Aan Komariah, 2011. Metode Penelitian Kualitatif. Penerbit Alfabeta. Bandung.

Irawan Soehartono. 2011. Metode Penelitian Sosial: Suatu Teknik Peneltitan Bidang Kesejahteraan

\section{Jurnal Sociopolitico}


Sosial dan Ilmu Sosial Laninnya. Remaja Rosdakarya. Bandung.

Joko Subagyo. 2011. Metode Penelitian: Dalam Teori dan Praktek. Rineka Cipta. Jakarta.

Mohammad Mahfud MD. 2003. Demokrasi dan Konstitusi di Indonesia: Studi tentang Interaksi Poltik dan Kehidupan Ketatanegaraan. Rineka Cipta. Jakarta.

Mufti, Muslim \& Didah, Durrotun. 2013. Teori-Teori Demokrasi. Bandung: Pustaka Setia,..

Ni'matul Huda. 2011. Ilmu Negara. Rajawali Pers. Jakarta.

Sartono Sahlan dan Awaludin Marwan. 2012. Nasib Demokrasi Lokal di negeri Barbar. Thafa Media. Yogyakarta.

Subekhi, Akhmad dan Jauhar Mohammad. 2012. Pengantar Manajemen Sumber Daya Manusia (MSDM). Jakarta: Prestasi Pustakarya Jakarta Indonesia.

Sugiyono. 2012. Metode Penelitian Kuantitatif, Kualitatif dan $R \& D$. Alfabeta. Bandung.

Widjaja, Haw. 2005. Otonomi Desa Merupakan Otonomi yang Asli dan Bulat. Jakarta:Raja Grafindo.

Gulo. 2010. Metodologi Penelitian. PT Gramedia. Jakarta.

Undang-Undang Dasar 1945.

Undang-Undang Nomor 43 Tahun 2014

Tentang Pelaksanaan UndangUndang Nomor 6 Tahun 2014.

Undang-Undang Nomor 6 Tahun 2014.

Peraturan Menteri Dalam Negeri Nomor 112 Tahun 2014 Tentang Pemilihan Kepala Desa. 